\title{
Acute focal bacterial nephritis
}

\author{
Tatsuji Maeshiro, ${ }^{1}$ Akira Hokama, ${ }^{2}$ Jiro Fujita ${ }^{1}$
}

1 Department of Infectious, Respiratory, and Digestive Medicine, University of the Ryukyus, Nishihara, Japan ${ }^{2}$ Department of Endoscopy, University of the Ryukyus, Nishihara, Japan

\section{Correspondence to}

Professor Akira Hokama hokama-a@med.u-ryukyu.ac.jp

Accepted 17 May 2014
CrossMark

\section{To cite: Maeshiro T,} Hokama A, Fujita J. BMJ Case Rep Published online: [please include Day Month Year] doi:10.1136/bcr-2014205199

\section{DESCRIPTION}

A 23 -year-old woman presented with fever at $38.2^{\circ} \mathrm{C}$, chills and right flank pain. She had felt the sensation of residual urine for 10 days. Physical examination revealed positive right costovertebral angle tenderness. The laboratory examination showed that white cell count and $\mathrm{C}$ reactive protein were elevated at $18600 / \mathrm{mm}^{3}$ and $8.68 \mathrm{mg} / \mathrm{dL}$, respectively. Urinalysis showed numerous white cells count. A CT scan disclosed a wedge-shaped decreased enhancement area without outer cortical contrast uptake (cortical rim sign) in the right kidney (figure 1). Acute focal bacterial nephritis (AFBN) was diagnosed and intravenous ceftriaxone was initiated. Escherichia coli grew on urine and blood cultures subsequently. She improved uneventfully and follow-up CT scans returned to normal findings.

AFBN, previously known as acute lobar nephronia, has been recognised as localised infection of the kidney without abscess formation. ${ }^{1}$ It is speculated to be a middle disorder between uncomplicated pyelonephritis and renal abscess. ${ }^{2}$ Characteristic CT findings are inhomogeneous or wedge-shaped parenchyma with decreased enhancement. ${ }^{3}$ These features

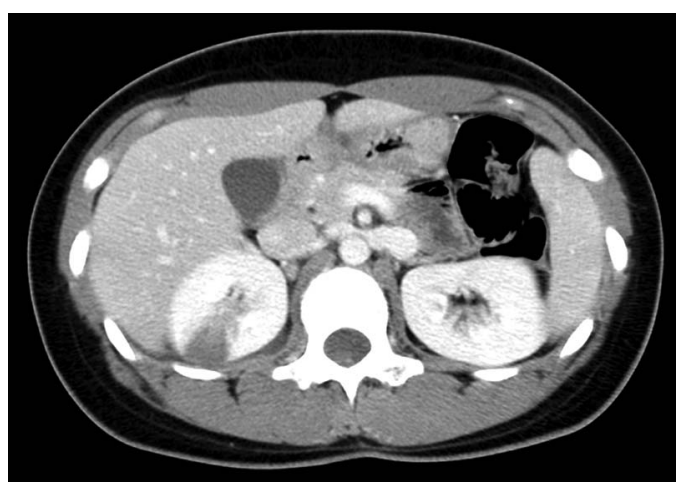

Figure 1 CT scan showing a wedge-shaped area with decreased enhancement in the right kidney. are crucial to differentiate AFBN from uncomplicated pyelonephritis, renal abscess and pyonephrosis, which may require different treatment strategies with more extensive interventions. ${ }^{3}$ The absence of cortical rim sign can be helpful in differentiating AFBN from renal infarction. ${ }^{4} E$. coli is the most common causative bacteria of AFBN. Most cases respond well to conservative treatment with antibiotics.

\section{Learning points}

Acute focal bacterial nephritis (AFBN) is a middle disorder between uncomplicated pyelonephritis and renal abscess.

- AFBN may present inhomogeneous or wedge-shaped parenchyma with decreased enhancement on $\mathrm{CT}$.

- These CT features are crucial to differentiate AFBN from uncomplicated pyelonephritis and renal abscess, which may require different treatment strategies.

Contributors TM and $\mathrm{AH}$ treated the patient. TM wrote the manuscript. $\mathrm{AH}$ reviewed the manuscript. JF supervised the study.

\section{Competing interests None.}

Patient consent Obtained.

Provenance and peer review Not commissioned; externally peer reviewed.

\section{REFERENCES}

1 Rosenfield AT, Glickman MG, Taylor KJ, et al. Acute focal bacterial nephritis (acute lobar nephronia). Radiology 1979;132:553-61.

2 Shimizu M, Katayama K, Kato E, et al. Evolution of acute focal bacterial nephritis into a renal abscess. Pediatr Nephrol 2005;20:93-5.

3 Soulen MC, Fishman EK, Goldman SM, et al. Bacterial renal infection: role of CT. Radiology 1989;171:703-7.

4 Ifergan J, Pommier R, Brion MC, et al. Imaging in upper urinary tract infections. Diagn Interv Imaging 2012;93:509-19.

Copyright 2014 BMJ Publishing Group. All rights reserved. For permission to reuse any of this content visit

http://group.bmj.com/group/rights-licensing/permissions.

BMJ Case Report Fellows may re-use this article for personal use and teaching without any further permission.

Become a Fellow of BMJ Case Reports today and you can:

- Submit as many cases as you like

- Enjoy fast sympathetic peer review and rapid publication of accepted articles

- Access all the published articles

- Re-use any of the published material for personal use and teaching without further permission

For information on Institutional Fellowships contact consortiasales@bmjgroup.com

Visit casereports.bmj.com for more articles like this and to become a Fellow 